\title{
No palco stanislavskiano
}

\author{
Jacó Guinsburg
}

Karl Theodor Kasimir Meierhold ou Meiergold nasceu a 25 de janeiro de 1875, em Penza, uma cidade provincial a sudoeste de Moscou, sendo o oitavo filho de Emil Fedorovitch, um judeu(1) alemão que adotara a religião luterana e emigrara muito jovem para a Rússia, fundando uma destilaria de vodca com a qual fez fortuna. Adito fanaticamente às suas raízes teutas, o pai conservou a cidadania original e procurou inculcar nos filhos os padrões da kultur bismarckiana. Mas o papel preponderante na formação de Meierhold coube à sua mãe, Alvina Danílovna, também de proveniência tedesca, do Báltico. Mulher interessada nas artes e nas coisas do espírito, transmitiu-lhe o gosto pela música e pelo teatro, ao mesmo tempo que foi responsável pelos contatos que desde cedo ele teve com a intelligentsia russa, pois recebia em sua casa artistas e intelectuais que passavam pela cidade ou lá se encontravam confinados pelo regime tzarista, em desterro administrativo, por motivos ideologicos e políticos.

$\mathrm{Na}$ escola, os progressos de Meierhold foram pouco promissores, tendo levado onze anos para concluir as sete séries do ginásio russo. Mas já nesse perfodo fazia-se notar pelas aptidões musicais, que pôde cultivar em estudos prolongados de piano e violino, e pelo particular interesse que dedicava à arte dos comediantes de província, cujas companhias visitavam Penza em suas tournées. Enquanto ginasiano, além de escrever críticas de teatro, deu os primeiros passos como intérprete, representando as figuras de Repetillov, em $\boldsymbol{A}$ desgraça de ter esplrito de Griboiédov, e de Kutéikin, em $\boldsymbol{O}$ menor de Fonvizin.

Com a morte do pai em 1892, seguiu-se um período de indecisão na vida de Meierhold. Para não servir o exército do Kaiser, pois fora registrado com a nacionalidade alemã, adotou em 1895 a cidadania russa e converteu-se ao cristianismo ortodoxo. Nesta ocasião trocou o triplo prenome pelo de Vsevólod, em homenagem a Vsevólod Garshin, um contista que se suicidara alguns anos antes e cujos contos o jovem estudante Karl, como a sua geração, admirava muito ${ }^{(2)}$, e adaptou o sobrenome para Meierhold, por razões de pronúncia, ao que consta ${ }^{(3)}$. "Foi a primeira de suas metamorfoses", diz Ripellino(4).

Em agosto de 1895, seguiu para Moscou com o propósito de cursar as ciências do Direito. Mas se o Teatro Máli o fascinava a ponto de empoleirar-se assiduamente na "torrinha" dos estudantes a fim de aplaudir o trabalho de atrizes como Fedótova e Ermelova ou de atores como Sadovski e sobretudo Lenski, a matéria jurídica não conseguia encantá-lo do mesmo modo. Em 1896, abandonou a faculdade, voltou para Penza, casando-se com Olga Mikháilovna Munt, uma atriz do pequeno teatro local. Aderiu então a uma idéia surgida entre exilados políticos, em cujo rol estava Alexei Rêmizov, escritor que exerceu naqueles anos forte ascendência sobre Meierhold, e jovens estudantes e intelectuais da cidade, que pretenderam, na linha dos narodniki ("populistas") e outros matizes socialistas e liberais da época, formar um Teatro do Povo com o fito de promover a ilustração e elevação das massas populares. No âmbito dessa atividade, in-
JACÓ GUINSBURG é professor de Teoria do Teatro da ECA-USP, editor da Perspectiva e autor de, entre outros, Stanislávski e o teatro de arte de Moscou (Editora

Perspectiva) e Leone de'Sommi um judeu no teatro da Renascença italiana (mesma editora).
1 Ao contrário de Angelo Maria Ripellino, no verbete "Mejerchold" da Enciclopedia dello spettacolo e em II trucos e l'anima P. 106, ou de Marc outros autores julgam duvidosa essa extraçăo. Nina Gourfinkel, por exemplo, em "Vsevolod Meyerhold", introdução a Le théatre théatral, p. 11. considera surpreendente "a certeza com que Ripellino... qualifica o pai de Meierhold de ebreo tedescon". de Meicrhold de Rudnilzky, o mais completo estudioso de Meierhold, năo faz, por sua vez, qualquer referéncia ao fato.

2 Ele próprio o afirma nos "Elements de biographie" (1921), in Ecrits sur le thestre P. 282 , N. 8, P. 324 , Op. cit. onde se 10. "Sua nergia e suas idéias me inspiram".

3 Tal versão, entretanto, é contestada pela especialista francesa que, na mesma passagem do trabalho já citado, diz que "a prova fonética năo se sustenta pois, antes da reforma do filoblogo Grot, o h alemáo era transhillogo Grot, a h alomáo era transcrito em russo indilerentemente por $k h$ ou por $g$..."

4 II trucco e l'anima, p. 106. 
terpretou, no verão de 1897 e 1898, vários papéis em peças de Ostróvski, como A noiva pobre e A floresta, imprimindo aos desempenhos uma feição realista, que copiava de Mikhail Sadóvski e Lenski, do Máli. Aparentemente o público apreciou os dotes do jovem amador e a imprensa local os comentou elogiosamente.

Em 1896, Meierhold decidiu preparar-se seriamente para uma carreira no teatro e, retornando a Moscou, enfrentou o exame do Instituto Dramático e Musical mantido pela Sociedade de Filarmonia. Aprovado, passou imediatamente ao segundo curso, onde foi aluno de Nemírovitch-Dántchenko, que, em Minha vida no teatro russo, assim descreveu a atuação de Meierhold ${ }^{(5)}$ :

“... mas em meus cursos também havia um agudo senso de rivalidade. Isto ocorria porque no último ano existiam vários alunos particularmente talentosos e também porque entre eles se achava Meierhold. Este moço, que mais tarde se tornaria diretor famoso, fora prontamente admitido à filarmonia no curso avançado e desenvolvia considerável atividade nas tarefas escolares, especialmente na direção do trabalho cooperativo. Era um fato nunca visto nas escolas de arte dramática: após cinco realizações preparadas e interpretadas, meus alunos pediram permissão para encenar minha peça $A$ última vontade de maneira quase independente. Pelo que me lembro agora, entreguei toda a apresentação às nove classes e no decurso de um mês esse texto enorme foi montado como espetáculo de início das aulas, que, entre outras coisas, deu grande oportunidade para Olga Kniper sobressair-se. O 'líder' do empreendimento foi Meierhold. Recordo-me de outra realização também - a da comédia francesa Le monde où l'on s'ennuie, de Pailleron. Meierhold com um colega adornaram o pequeno palco escolar com excelente qualidade de direção e não pequeno engenho mecânico. Como ator, ele não parecia aluno. Denotava certa dose de experiência e dominava os papéis com inusitada rapidez. Além disso, manejava notável variedade de papéis - desde o trágico de Ivã o Terrível até o cômico de um vaudeville de um ato com canções. Não lhe foi dado criar qualquer espécie de figuração de um modo especificamente brilhante. Mas era de fato muito inteligente. Tchekhov disse dele (nas Vidas solitárias de Hauptmann): 'É muito agradável ouvi-lo, porque se pode acreditar que entende tudo quanto diz'. E isto não é algo raro quando um ator desempenha o papel de uma pessoa astuta ou inculta? Meierhold tinha mais consciência do que outros no tocante à Tchekhov-o-poeta".

Em seu exame final, Meierhold interpretou sete personagens diferentes, entre as quais, em Vassilissa Melentieva de Ostrovski, a figura de Ivã o Terrf́vel.

Quando Dantchenko e Stanislávski criaram em 1898 o Teatro de Arte de Moscou, o jovem ator, juntamente com Olga Kniper, Moskvin e outros alunos de Dantchenko na Sociedade de Filarmonia, passou a integrar a nova companhia. Meierhold ficou entusiasmado com a perspectiva que se lhe abria: "Tenho a impressão que, embora meus estudos estejam terminados, fui admitido numa Academia de Arte Dramática. Quantas coisas interessantes, originais, novas e inteligentes! Não e talento que Alexeiev tem, não, este encenador-professor tem gênio. Que rica crudição, que imaginação...", escreve ele à sua mulher Olga Mikhailovna, numa carta ${ }^{(6)}$ enviada de Pushkino, a 28 de junho de 1898. O que o atráa especialmente era a capacidade de Stanislávski criar, por meios cênicos, a atmosfera necessária para encenar o repertório moderno.

Trepliov, em A gaivota de Tchekhov, apresentada sob a direção de Dantchenko;

5 My life in the russian theater, pp. 122-3.

6 Ecrits sur le theatre, t. 1, p. 48.

7 Apud Vsevolod Emeliovich Meyerhold: the pattern of a master, William hold: the pattern of a master, William
Keeler, tese de mestrado, Universidade da California, 1969.

8 A carta de Tchekhov mostra que não é tăo infundada, como pretende Nina Gourfinkel (op. cit. no trecho mencionado) a posiça de Ripellino embo a na ra náo se possa considerar Meierhold um comodiante Iracassado, mas sim um outro tipo de ator, como demonstraria em inúmeras ocasióes no curso de seu trabalho como diretor $e$ ator.

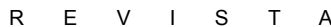
Vassili Schuiski, em Czar Fiodor Ioanovitch de A. Tolstói; Malvolio, em A décima segunda noite de Shakespeare; Johannes Vorckerat, em Homens solitários de Hauptann; Marquês de Forlipopoli, em La locandiera de Goldoni; Príncipe de Aragão, em $O$ mercador de Veneza (Shylock, na montagem de Stanislávski); Ivã, em $A$ morte de Ivã o Terrtvel de A. Tolstói; Barão de Tuzenbach, em As três irmãs de Tchekhov - eis algumas das principais personagens que lhe coube encarnar nas quatro temporadas incompletas (1898-1902) em que participou do elenco do Teatro de Arte.

Como ator, Meierhold não logrou impor-se irrestritamente à crítica. Não que lhe faltasse temperamento ou técnica. Mas seu corpo espichado e pernalta, de movimentos bruscos e angulosos, agitava-se nervosamente no palco, numa crispação obstruidora, introduzindo uma nota dissonante, antilírica, no gestus do verismo stanislavskiano, em que o intimismo da vivência, a naturalidade da expressão e a harmonia da representação 
eram os critêrios básicos da interpretação atoral. Além disso, este desempenho febricitante e seco, que convertia as personagens em figuras neurastênicas, doentias ou pedantes, irritadiças, enfastiadas, sem mobilidade espiritual, ressaltava por suas incidências grotescas ou luciferianas, traços que seriam certamente de grande força e proveito num teatro de composição sintética, como o expressionista, por exemplo, e não em um palco naturalista, de exposição mimética e analítica.

Tchekhov, com quem travara amizade em setembro de 1898 , durante os ensaios de A gaivota e que era uma espécie de deus votivo de Meierhold nesta ocasião, escreveu, a propósito de sua atuação como Johannes Vorckerat em Einsame Menschen (Homens solitários), de Hauptmann: "Onde no mundo você já viu pessoas jogando-se de um lado para outro, pulando e agarrando a cabeça com as mãos? O sofrimento deveria ser expresso tal como é na própria vida, não pela ação de braços e pernas, mas por um tom de voz ou um olhar; não pela gesticulação, mas por um movimento gracioso. Manifestações espirituais sutis, que são naturais em pessoas cultivadas, deveriam ser expressas exteriormente também. Você vai aduzir consideraçōes de encenação. Mas nenhuma consideração pode justificar a falsidade" (Carta a Olga Kniper, em janeiro de 1900)(7).

Todavia, cabe pensar que esta qualidade de seu trabalho de ator não era apenas resultado da personalidade de Meierhold(8) somada à crise espiritual em que estava mergulhado e que o levava a julgar a existência como algo sombrio $\mathrm{e}$ indigno de qualquer esforço. $\mathrm{Na}$ verdade, a profunda insatisfação que chegou mesmo a minar-lhe a saúde, a ponto de obrigá-lo a uma temporada de cura na Criméia, durante o verão de 1900 , era produto também de uma revolta que começava a avolumar-se em seu íntimo contra o estilo do Teatro de Arte e sua estrita obediência realista. Em decorrência, o metteur-en-scène, que se achava latente no jovem comediante, incitado talvez pelas próprias irrealizações deste e pelo espírito de indagação intelectual, que era inato em Meierhold, pôs-se a procurar formas de desempenho, induzindo-o a fazer experiências com movimentos estilizados e conformações exageradas de expressão.

Seja como for, é curioso observar que a contestação ao stanislavskismo surge, em Meierhold, pelo menos no início, de duas fontes aparentemente contraditórias. De um lado, como evidenciava o fato de identificar-se de tal modo com Trepliov em seu an-
Como ator, Meierhold não logrou

impor-se irrestritamente à crítica.

Não que the faltasse temperamento ou

técnica. Mas seu corpo espichado

agitava-se nervosamente no palco,

introduzindo uma nota antilírica no

"gestus" do verismo stanislavskiano

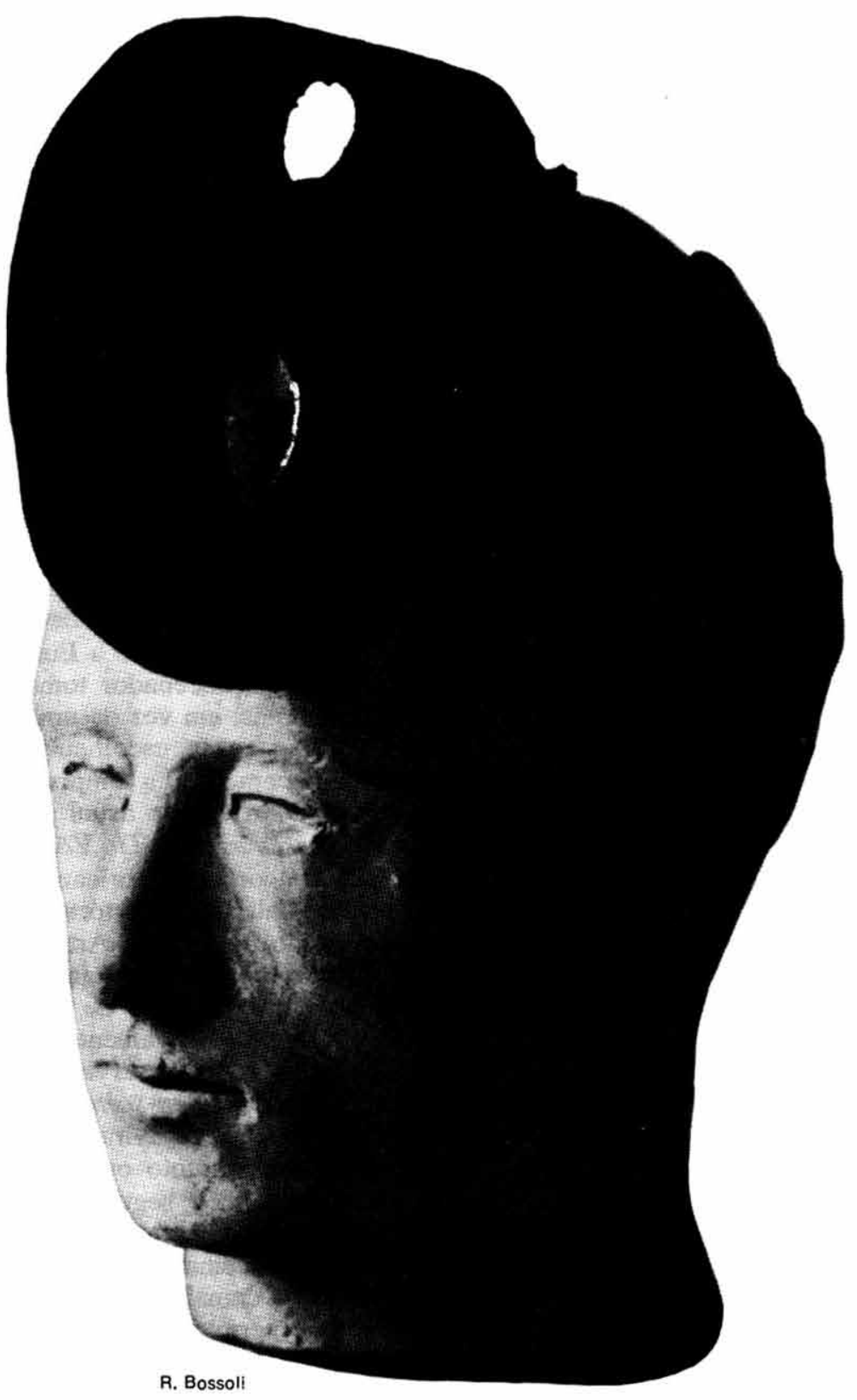


seio pungente por uma nova arte que chegou a sentir carnalmente o sofrimento da personagem de Tchekhov, realizando assim paradoxalmente o ideário interpretativo do Teatro de Arte, as influências decadentistas, esteticistas e simbolistas o tornavam especialmente sensível a uma arte cênica que procurasse captar "a quintessência da vida"((9), dos homens e dos acontecimentos; $\mathrm{e}$, mais ainda, as idéias em seu aspecto eterno, pois a verdadeira forma artística não devia ser configuração externa, imitativa, porem, como a seu modo já declarara o idealismo hegeliano na Estética, "o luzir sensível da idéia". De outro lado, seja por efeito de suas concepçōes políticas e sociais, carregadas de populismo e socialismo pedagógico e artístico, seja porque as bases de sua estética aparentemente elitista residiam no poder irradiante dos símbolos e na capacidade captadora da imaginação, elementos de uma arte altamente abstrata, mas por isso mesmo dotada de maior potencial de universalização, o fato é que a representação realista ou naturalista de Stanislávski pareciam-lhe confinar a experiência teatral ao palco, sem solicitar uma resposta ativa do espectador. "Os espectadores não devem observar, mas participar da peça", pensava ele. Sentia que a platéia não tinha existência real para Stanislávski. O palco do Teatro de Arte de Moscou se lhe afigurava uma sala particular do grande diretor, em que este costumava montar intricadas máquinas realistas, para a sua própria satisfação por trás da "quarta parede".

Assim, embora estas idéias não estivessem então totalmente definidas, não é de pasmar que, após algumas hesitações, estimulađo por injustiças de que teria sido vítima na reorganização do TAM e, mais ainda, talvez pelo desejo de experimentar a direção em termos próprios, haja decidido sair do elenco do Teatro de Arte, em plena temporada de 1902, quando era mais uma vez apresentada a peça de Tchekhov, As três irmãs. Meierhold foi substituído por Kochalov e, ao que parece, seu afastamento não foi grandemente lamentado na época, pois há registro inclusive de um incidente mais ou menos violento entre ele e Stanislávski, que teria se recusado a recebê-lo sequer em sua casa, por causa de diz-que-diz de bastidores envolvendo Dantchenko e que seria de autoria de Meierhold.

Com Alexander Koscheverov, trânsfuga como ele do Teatro de Arte, e mais 27 atores, Meierhold, após uma viagem pelo norte da Itália, organizou um grupo que recebeu o nome de Troupe de Artistas Dramáticos Russos e que se propunha a levar um novo estilo de espetáculo às províncias do Império. Meierhold começou por uma cidade da Criméia, Kherson, cujo teatro municipal arrendou para a temporada de 1902-03. A iniciativa era arriscada, pois nem o diretor nem os demais partícipes do elenco dispunham de recursos materiais para financiar as montagens. Tchekhov mesmo se mostra preocupado com a aventura, escrevendo a O. Kniper: "Gostaria de encontrar-me com Meierhold e falar-lhe, sustentar seu ânimo; em Kherson não terá uma tarefa fácil. Lá não existe ainda um verdadeiro público de teatro, precisam ainda da barraca de feira. Kherson não ê a Rússia e não é a Europa". Mesmo assim, trabalhando com dinheiro emprestado, o jovem encenador tomou o rumo inverso do que era costumeiro entre os elencos provinciais: em vez de um repertório imenso, pois raramente a mesma peça era apresentada duas vezes, escolheu um número reduzido de textos, o que, em caso de fracasso, colocava em risco a temporada, e se pôs a ensaiá-los por mais de cinco semanas, o que dobrou o orçamento usual por temporada. As obras escolhidas inclúam, alem de A gaivota, As três irmãs e Tio Vânia de Tchekhov, dramas de Hauptmann e Ibsen.

Embora não concordasse teoricamente com Stanislávski, na prática, o estilo das montagens, para não falar do repertório, fazia de sua companhia uma espécie de réplica e sucursal menor do Teatro de Arte. O próprio Meierhold afirmou, anos mais tarde(10): "Como diretor, comecei imitando servilmente Stanislávski. Na teoria, não aceitava muitos pontos nos métodos de suas primeiras encenações, mas quando eu mesmo me pus a dirigir, segui passivamente suas pegadas. Não o lamento, porque foi uma fase de curta duração; além disso, serviu de excelente escola prática...".

Mas se a linha da mise-en-scène não constituíra maior novidade em Moscou, na distante Kherson os espectadores viram-se, com surpresa e agrado, diante de um elenco que atuava como um conjunto organizado e harmônico, em função do que era dito pelas personagens em cena e segundo uma ordem de marcação estudada e coerente. Isto, ao contrário dơ que acontecia então com as troupes de província, cujos atores declamavam suas tiradas com ademanes exibicionistas, sem se atribular com um relacionamento mais orgânico com os demais intérpretes, nem com o espetáculo como tal. A temporada foi bem-sucedida e permitiu que o elenco excursionasse pelas cidades do sul, na primavera. Em Sebastopol, Meierhold levou pela primeira vez uma.peça de Maeterlinck, $A$ intrusa. 
Animada com os resultados, a companhia programou uma segunda estada (1903-04) em Kherson. A direção ficou agora unicamente em mãos de Meierhold que, desde logo, anunciou modificações substanciais na orientação artística do conjunto. Tratava-se de dar representação cênica mais definida às buscas das correntes modernas em arte e, sobretudo, na dramaturgia, que àquela altura já reunia um número ponderável de obras a exigir uma configuração teatral adequada - reputava Meierhold. Para tanto rebatizou o grupo, que passou a chamar-se Confraria do Novo Drama (Tovarischestvo Novoi Drami). Além disso, confiou ao simbolista Alexei Remízov, a quem continuava ligado, a supervisão literária da troupe. Com ele, escolheu um repertório que compreendia textos de Maeterlinck, Schnitzler, Sudermann e do jovem dramaturgo polonês, de tendência "decadentista", Stanislav Przybyszewski (1869-1927), cuja peça Neve, levada a 19 de dezembro de 1903, assinala, segundo alguns autores, o primeiro passo de Meierhold no caminho estilístico de um teatro despojado do lastro verista, como já pedia Briussov(11) em 1902, e de uma encenação não-mimética e não-representacional. Remízov descreveu o espetáculo como "uma sinfonia de neve e inverno, de apaziguamento e incontivel anelo"(12), mas a qualificação de "sinfonia ultravioleta" talvez encerre, na sua sinestesia, um testemunho mais preciso do estilo da montagem. Data também desta época, com a união da partitura de Mendelssohn e o texto shakespeariano de Sonho de uma noite de verão, o início das pesquisas meierholdianas sobre o espetáculo de base musical.

Todavia, no todo, tais tentativas de materializar em termos cênicos uma reação estilística contra o naturalismo do Teatro de Arte produziram resultados bastante modestos e circunscritos, do ponto de vista artístico. Ainda assim, apesar de apupos e assobios face às invocaçōes evanescentes da musicalidade místico-simbolista em Neve, ao fim das quais uma parte da platéia até se recusou a sair da sala, pois, disseram eles "a peça não pode ter terminado, uma vez que ninguém ainda não compreendeu nada"(13), verificou-se que, seja por efeito da temporada anterior ou por tentação da novidade escandalosa, o público favoreceu os espetáculos, ao menos a julgar pelo êxito de bilheteria ocorrido. E se a crítica não se sentiu tão atraída pelo que lhe foi dado ver, não há dúvida de que, graças aos artigos de Remízov para Vesi, uma revista moscovita ligada aos simbolistas, estas apresentações ajudaram a difundir o nome de Meierhold nos meios intelectuais russos, principalmente entre os que propugnavam pelas novas tendências em arte.

Era o momento em que tais correntes faziam-se ouvir com crescente nitidez. Desde 1898, com a revista Mir Iskustva (Mundo da Arte), encabeçada por Serguei Diaghilev, as idéias estéticas do fin du siècle europeu começaram a ser divulgadas com maior intensidade nos ćŕculos artísticos russos, conquistando um auditório interessado, sobretudo entre a nova geração, sob a égide de Dostoiévski, Soloviov, Nietzsche, Bergson, Ibsen e os simbolistas franceses. Os nomes de Balmont, Briussov, Ivanov surgiam com a lufada do "novo vento" na poesia. As telas e as concepções de Benoit, Bakst, Golovin, antecedidos por Serov e Vrubel, destacavam-se cada vez mais nas salas de exposição e discussão, afetando inclusive a cenografia teatral que foi submetida por eles a transformações importantes, precisamente neste período, com implicações para o conjunto da arte cênica e não apenas para a ópera ou o bale, onde elas foram primeiro experimentadas. Assim, não é de admirar que em semelhante contexto de idéias e tendências o trabalho do jovem diretor e suas pesquisas teatrais despertassem interesse.

Isso, entretanto, não significa que Meierhold já tivesse encontrado o que procurava. Muito pelo contrário, ainda se achava a meio caminho entre o Teatro de Arte e a efetiva criação simbolista com a encarnação do prinć́pio da "estilização" ou da "convenção consciente" no palco, como prova a sua temporada seguinte (1904-05) na capital da Geórgia. Com efeito, em Tŕflis, onde lhe fora oferecido um bom contrato no teatro recém-construído pela Sociedade Artística e equipado com palco giratório, mecanismos de elevação de nível no tablado e iluminação moderna, estreou com As três irmãs.

Aparentemente a montagem deveria traduzir uma visão nova do texto, algo similar
11 Seu trabalho pioneiro, publicado sob o título de "Verdade inútil" em mundo da arte, exerceu forte impacto mondo da arto, exercous torto impacto ais do jovem diretor, como fica patente em "Presságios literários do novo teatro", artigo que comenta e cita largamente a posiçăo de Briussov e que Meierhold in cluiu em seu livro Do teatro, 1912 (ct. Ecrits sur to the trete t 1, Pp. (ct. Ecrits sur to theatre, t. 1. pp. 105-9). N. Evreinotf em Histoire du theatre russe, p. 359, e Denis Bablet, em Le décor du theatre, p. 172, tam bém ligam expressamente a Briussov as origens do "teatro da convençăo" meierhoidiano.

12 In Vesi, (A balança), 1904, apud Me yerhold on theater, ed. Edward Braun, p. 19.

13 Como regístra Nina Gourfinkel, Le theatre theatral, p. 22. 
àquela de que Meierhold fala em uma carta a Tchekhov, em janeiro de 1904, com respeito ao Jardim das cerejeiras, encenado anteriormente em Kherson: "Vossa peça é abstrata como uma sinfonia de Tchaikóvski. É pelo ouvido que o régisseur deve primeiro apreendê-la. No terceiro ato, sobre o fundo de uma estúpida agitação - e é esta agitação que e preciso entender - o Horror penetra insensivelmente as personagens, sem que elas se apercebam do fato: 'o cerejal foi vendido'. Elas dançam. 'Vendido'. Elas dançam. E assim até o fim. Quando se lê a peça, o terceiro ato produz uma impressão análoga àquele zunido nas orelhas que o doente, em vosso relato $O$ tifo, julga ouvir. Uma espécie de prurido. Uma alegria na qual se escutam os ruídos da morte. Há nesse ato algo de horrorffico, ao modo de Maeterlinck..."(14). Vê-se que Meierhold faz uma leitura nitidamente simbolista da peça tchekhoviana, transmutando-a num drama de ressonância mística e ressaltando, num texto considerado por seu autor como uma "comédia"(15), um ríctus de horror metafísico, que converte as personagens em "máscaras fantasmagóricas" de um mundo em decomposição, cujos sinistros rumores deveriam assaltá-las sob a forma de fatf́dicos pressentimentos e cujas mefíticas ações deveriam desfazê-las em miasmas trágicos de uma existência absurda. Mas, se o princípio musical da construção dramática e até o princípio plástico da estilização cênica, bem como o elemento de grotesco, tão típicos da visão teatral meierholdiana, já surgem aí em germe, "nessa dança macabra de marionetes em sua barraca de feira..." com "o acompanhamento dissonante, o rangido monótono da orquestra provinciana que ritma o baile dos cadáveres vivos (os pequenos burgueses)... ${ }^{(16)}$, ainda assim esta linha de interpretação, ao que parece, não logrou, pelo menos em As três irmãs, verter-se numa linguagem cênica de fato inovada e inovadora. Pois, segundo escreve um crítico local, se os comentários em circulação criaram no público a expectativa de que "a Confraria do Novo Drama ia proporcionar-lhe algo de 'novo', algo que Tíflis jamais vira antes... Quando apresentada, a 'nova coisa' tão ansiosamente aguardada, resultou ser sobretudo uma encenação extraordinariamente esmerada da peça, com numerosos detalhes menores, todos inspirados pelo desejo de alcançar um efeito máximo de ilusão possível"(17), ou seja, de recriação da realidade nos bons termos de Stanislávski.

Esse tom artístico prevaleceu, como tudo leva a crer, durante a temporada inteira na capital da Geórgia. Além de As três irmãs, o repertório compreendia $O$ sino submerso e Schluck e Jau, de Hauptmann, bem como Um inimigo do povo de Ibsen e Os veranistas de Górki, cuja exibição foi proibida pela polícia. Mas a única tentativa de mostrar um espetáculo mais ousado cenicamente foi uma remontagem de Neve, na qual a mise-enscène sofreu alterações, sendo empastada de cores tão lôbregas que espantaram a crítica e não menos o público, que começou a escassear.

Se, afora A liturgia da beleza de Balmont, encenada em Nicolaiev, não houve outras experiências no palco das aventuras provinciais da Confraria do Novo Drama, nesse ano, Meierhold tampouco abandonou os seus projetos de renovação no teatro e, tão logo apareceu uma oportunidade, enveredou novamente pelas vias da pesquisa vanguardista, com o intuito de levar a uma platéia, quiçá melhor armada que a de Tíflis para apreciá-lo esteticamente, a expressão do que entendia por "estilização" e "quintessência da vida" na cena dramática. E quem lhe permitiu realizar essa tentativa capital para a evolução de sua obra não foi outro senão Stanislávski.

Em 1904, o Teatro de Arte encenara uma trilogia de peças de um ato de Maeterlinck, Os cegos, A intrusa e Interior, mas a montagem fracassara porque, como o próprio Sta-

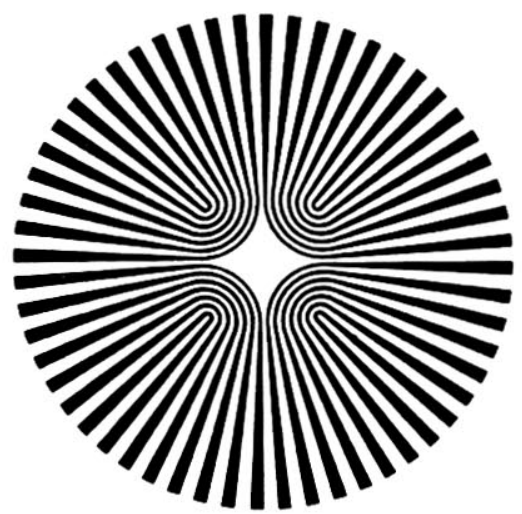
nislávski percebera, a linha adotada pela direção não conseguia dar moldagem cênica adequada às abstrações místico-poéticas do "novo drama". Stanislávski começou a perguntar-se, com a sua usual inquietação: "Meu Deus!... Será possível que nós, artistas do palco, estamos condenados pela materialidade de nossos corpos a exprimir eternamente um grosseiro realismo e nada mais? Será que estamos destinados a não ir mais longe que os realistas foram na pintura, em seu tempo? Será que somos apenas precursores na arte cênica? E o balé e seus melhores expoentes, Taglioni, Pavlova e 
outros?... Não há aí separação de materialidade do corpo? E os acrobatas que voam como pássaros de um trapézio a outro? Nunca se poderia crer que possuem um corpo. Isto significa que pode haver uma separação do corpo. Ela deve ser descoberta e desenvolvida..."(18).

Essas dúvidas e indagações ocorriam numa hora em que a morte de Tchekhov privava o Teatro de Arte de uma das principais fontes de sua originalidade estética e em que a corrente simbolista ganhava foros certos de cidadania na vida artística russa. Em 1904, Alexsander Blok, a principal força poética da nova escola, publicava a sua primeira coletânea com os Versos sobre a beltssima dama, Vera Komissarjevskaia abria um teatro próprio em S. Petersburgo e Isadora Duncan apresentava-se pela primeira vez na Rússia. A procura de uma espiritualidade mais profunda, inclusive no palco, começava a fazer-se em "estúdios" que, evitando a pesada carga da organização teatral vigente, se lançavam pelas sendas de experimentação cênica, como era o caso do Teatro da Tragédia de Vachkevitch, com a sua tentativa de vincular arte e religião, de suscitar um clima de devoção e iluminação interior, através de efeitos especiais de luz, de véus e cortinados a compor sugestões imateriais para espectadores que deveriam acolhê-las em piedosa comunhão e contemplação. Foi então, enquanto se teciam em torno dos anseios da sociedade russa estes fios da arte simbolista do inefável, que Stanislávski e Meierhold voltaram a encontrar-se.

Ambos estavam à espreita de novas formas, com a diferença, conforme as palavras do próprio Stanislávski, de que "eu apenas me empenhava na busca do novo, sem conhecer quaisquer trilhas e meios de alcançá-lo, enquanto que Meierhold, parecia, já havia descoberto novos caminhos e métodos, mas não os utilizara em parte por causa de dificuldades materiais e em parte porque seu elenco era fraco. $O$ destino me pôs mais uma vez em contato com o homem que me era mais necessário em minha busca. Decidi ajudar Meierhold em seu novo esforço, que, se me afigurava então, coincidia com o meu"(19). Isso se deu em 1905.

A julgar pelo "projeto de uma nova companhia dramática junto ao Teatro de Arte de Moscou"(20) que enviou a Stanislávski em 1904, não podia haver sombra de dúvida quanto aos propósitos inovadores e heterodoxos de M eierhold. Muito embora assegurasse que o novo grupo devia "conservar laços estreitos com seu irmão mais velho, o Teatro de Arte de Moscou"21, proclamava, uma linha antes, que o novo teatro não devia "imitar" o que já fora realizado, mas sim "forjar" uma personalidade específica, pois só é bela a arte individualizada", mesmo porque cumpria "ajudar com todas as forças o Teatro de Arte a não perder este encanto, precisamente o de ser um teatro de vanguarda". Por isso Meierhold se propunha a conduzir "com um fanatismo ardente suas pesquisas relativas à poesia e à mística do novo drama", elaborar "uma disciplina muito severa, não acadêmica e tediosa, nem policial, mas aquela que deve existir entre pioneiros", substituir os atores que haviam deixado ou iriam deixar "os quadros do Teatro de Arte, por atores de um novo tipo, febricitantes ademais de energia criadora”. Só assim, ao ver de Meierhold, se abriria para o Teatro de Arte uma nova era e ele se tornaria de novo um teatro de vanguarda. Ou, mais do que isso, na mística sócio-estética que guiava então o pensamento meierholdiano - um eremitério, uma cela, onde o ator, "sempre um cismático", pudesse "criar na solidão, inflamar-se aos olhos de todos no êxtase da criação" e depois "reintegrar a cela" na vida social, pois "a cela implica não um distanciamento da sociedade, mas a capacidade de erigir o trabalho criador em celebração religiosa'"(22).

Os dois responsáveis pelo empreendimento compreenderam que a realização de um programa desta ordem requeria formas de trabalho para as quais, como acentuou Stanislávski, "não havia lugar no teatro (corriqueiro) com seus espetáculos diários, suas tarefas complexas e seu orçamento estrito. Precisávamos de uma instituição especial, que Meierhold chamou adequadamente de 'estúdio teatral'. Não era nem um teatro plenamente desenvolvido, nem uma escola para principiantes, mas um laboratório para atores mais ou menos maduros'"(23).
14 Écrits sur le theatre, t. 1, p. 66.

15 Subtftulo dado por Tchekhov ao texto.

16 "Theâtre naturaliste et théatre d"états d'âmes", in Écrits sur le theatre, p. 98.

17 In Tiflisski listok, Tfflis, 28 de setem bro de 1904, p. 2; apud On Meyerhold, p. 18, introduçăo.

18 My life in art. Trad. G. Ivanov-Mumjiev, p. 331.

19 My life in art, p. 331.

20 "Projet d'une nouvelle troupe dramatique près Théatre d'Art de Moscou". in Ecrits.... t. 1, 1905, pp. 70-3.

21 Todas as citaçס̄es subseqūentes, até o fim do parágrafo, são extraf́das do texto supramencionado.

22 Apesar do seu caráter místico e de estarem ligadas a uma proposta muito em voga no meio intelectual da época, a da fuşâo de arte e religiăo, escas ideias sấo por certo a matriz de tas ideias sấ por certo a matriz de futuras concepçoes meierholdianas sobre a socializaçăo do teatro $\theta$ a teatralizaçăo, quando não da vida, ao modo de Evreinoff, ou da sociedade em geral, ao modo de certos radicais do "lefismo", pelo menos do trabalho na fábrica e do lazer proletário.

23 Op. cit., p. 332.

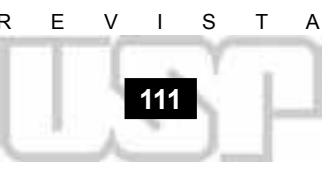


24 Le Thesatre-Studio", in Ecrits sur le theatre, p. 89.

25 Como esclarece o proprio Meierhold, no art. cit. ibidem.

26 Cf. art. cit., p. 91.

27 Ibidem.

28 Ibidem.

29 Ibidem.

30 "Mot d'introduction avant la première de La mort de Tintagiles à Tiflis", 19 de março de 1906, in Ecrits..., pp. 79-80. Escrita poucos meses depois de terminado o Teatro-Estúdio, concigna com clareza a diretriz estética Meierhold, naquele momento.

31 Neste sentido, săo ilustrativas as notas do caderno de direção que Meierhold manteve na época em que Meierhold manteve na época em que morte de Tintagiles os seguintes princlpios: "1. Experiencia da forma e năo de emoçбes psicológicas isoladas; 2 . Um sorriso para tudo; 3. Nunca usar tremolos; 4. Ler as linhas como se estivesse oculta em cada fracem cada fraonipotente; 5. Firmeza de tom, pois se for borrado soará como elegantemente 'moderno'; 6 . Teatro imovel; 7. Năo arrastar o final das palavras. $O$ som deve cair em grande profundidade. Deve ser claramente definido âo tremer no ar: 8 . Como um plano. náo tremer no ar, 8 . Como um plano. . Näo falar emo rápida tagarelice. 9. Não falar em rápida tagarelice. Calma épica: 10 . Movimentos de Madona". In Meyerhold, Marjorie L Hoover, p. 25.

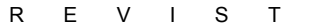

Nomeado diretor artístico do novo experimento, Meierhold reuniu à sua volta, além, de um núcleo de elenco formado por alguns dos melhores atores da companhia que vinha dirigindo, a Confraria do Novo Drama e alunos do Teatro de Arte, os cenógrafos Sapunov, Sudeikin e Ulianov, entre outros, o musicista Ilia Satz, bem como o poeta simbolista Valerii Briussov, a quem foi confiada a direção do setor literário do TeatroEstúdio.

No primeiro encontro entre os membros do novo grupo, em maio de 1905, os seguintes pontos vieram à baila, como que configurando uma espécie de programa: "as formas contemporâneas da arte dramática sobrevivem a si próprias já faz muito tempo. $\mathrm{O}$ espectador moderno exige outros procedimentos técnicos. O Teatro de Arte chegou ao virtuosismo no plano do naturalismo e da simplicidade natural da interpretação. Mas apareceram peças que exigiam novas técnicas de encenação e interpretação. $O$ TeatroEstúdio deve tender para a renovação da arte dramática por meio de novas formas e novas técnicas de interpretação cênica"(24).

A questão essencial, portanto, era a de descobrir novas formas e procedimentos teatrais que se ajustassem ao estilo e às idéias do novo tipo de drama, ou seja, fundamentalmente, o drama simbolista. Para tanto, os encenadores e cenógrafos se retiraram por um mês para a oficina de maquetes do Teatro de Arte(25). Ar, começaram a moldar os projetos para a montagem das seguintes peças: A cavalaria russa de Polevoi, Neve de Przybyszewski, $O$ mercador de sol de Rachilde, Colega Krompton e A festa da paz de Hauptmann, A esfinge de Tetmayer, As sete princesas de Maeterlinck e A mulher na janela de Hofmannsthal.

Mas foi com os trabalhos para $A$ morte de Tintagiles de Maeterlinck que, devido à recusa de Sapunov e Sudeikin de reduzirem suas concepções do cenário a um simples detalhamento tridimensional em gesso, surgiram as primeiras definições cênicas de Meierhold e de seu grupo, que levantaram contra a modelização naturalista em maquete o projeto estilizado em duas dimensões, com recurso atê então desconhecido aos efeitos de cor e de luz para objetivos nitidamente pictóricos no palco. Assim, no primeiro ato de Colega Krompton, o cenógrafo Denissov, em vez de construir no palco um aposento de tamanho natural, com todo o mobiliário e demais pertences, pintou "as manchas de cor mais vivas, mais importantes, características de um atelier'(26) de pintor.

Este princípio de estilização, que, para Meierhold, nada tinha a ver com a reprodução fotográfica do estilo de uma época ou de um evento, mas estava indivisivelmente "vinculado à idéia de convenção, generalização e símbolo..."(27), ganhou grande desenvolvimento nos estudos cenográficos que foram efetuados para a planejada montagem da peça de Hauptmann, Schluck e Jau. Ulianov conseguiu, neste caso, em seus esboços, uma síntese altamente funcional e convincente do ponto de vista estético-teatral, afir$\mathrm{ma}^{(28)}$ o diretor do Teatro-Estúdio, quer no que tange aos elementos de época quer no tocante aos de gênero, permitindo que o espectador fosse colocado imediatamente no quadro ambiental da peça. Pois, além da concreção visual de um castelo do século XVIII, de um reino em azul e rosa, do biscuit e do minueto, criou desde logo a sugestão de um mundo alambicado, ocioso e supérfluo, explorando as possibilidades de acumulação e reiteração do rococó e levando-as, da fantasia ao fantástico, para o limiar do absurdo, pela ostentação desmedida do luxo e da riqueza, enfatizados em objetos descomunais, como o leito da rainha ${ }^{(29)}$. Diante disso, a simples presença dos dois pobretões, Schluck e Jau, em sua aventura onírico-etnlica, produzia de chofre, por contraste, um impacto grotesco, que dava o leitmotiv da interpretação, pondo-a a correr pelos trilhos da tragicomédia e da sátira, como pretendia a proposta da encenação meierholdiana.

Mas os objetivos do Teatro-Estúdio não se resumiam no intuito de submeter ao fulcro plástico o conjunto da representação. Na verdade, já então, Meierhold não só prestava culto incondicional ao espírito wagneriano-nietzscheano em que a música era "a maior das artes"(30) e portadora das significações últimas, como subordinava, embora de uma maneira ainda imprecisa, o espetáculo todo a um padrão rítmico-musical, considerado como fato básico na síntese pretendida, devendo-lhe obediência inclusive o desempenho do ator, tanto no gesto quanto na fala ${ }^{(31)}$.

A atuação especificamente devia integrar-se de tal maneira no fundo cenográfico que o intérprete viesse a perder, por assim falar, a espessura, convertendo-se numa espécie de massa ou mancha de cor a destacar-se apenas do décor. Seu gesto, solene e pausado, isento de tudo o que pudesse perturbar-lhe o desenho rítmico e plástico, cristalizaria a música de uma recitação friamente orgiástica e comporia, com o corpo atuante, uma estatuária cênica que trouxesse, não só pelo dito mas sobretudo pelo não-dito, pelas áreas 
de sombra e silêncio, os signos conotativos dos mistérios inefáveis. Hieraticamente, qual esculturas ou pinturas de sacerdotes oficiando seus ritos, essas figuras tramariam, em baixos-relevos ou afrescos vivos, no templo teatral perante seus crentes-espectadores, a procissão das tensões e metamorfoses dramáticas ${ }^{(32)}$.

Mas estava escrito que o Teatro-Estúdio não celebraria publicamente os misterios de Dionísio. Apesar do interesse da imprensa moscovita em torno da nova companhia, que devia estrear em outubro de 1905, e do entusiasmo que os ensaios parciais provocaram em todos aqueles que puderam assistir a eles, inclusive Górki e Stanislávski, o projeto em sua íntegra não ultrapassou a fase dos ensaios gerais de $A$ morte de Tintagiles, Schluck $e$ Jau e algumas peças de um ato $^{(33)}$. Os motivos que induziram à liquidação do estúdio da rua Povarskaia são assim expostos pelo diretor do Teatro de Arte:

\begin{abstract}
"Depois de vê-los (os ensaios) tudo se tornou claro. Os jovens e inexperientes atores passaram o exame público, com a ajuda do diretor de cena, em excertos, mas quando tentaram representar em tramas de grande conteúdo interior e sutil configuração de personagem, e de uma forma irrealística, mostraram que eram infantilmente desamparados. $\mathrm{O}$ talentoso diretor de cena (Meierhold) procurou salvar os atores com seu trabalho. Em suas mãos eles eram apenas barro com o qual moldou seus interessantes grupos e mises-enscène, para realizar suas idéias. Mas com intérpretes carentes de técnica de desempenho, o diretor de cena só conseguiu demonstrar suas idéias, princípios, buscas. Não havia nada que pudesse dar-lhes vida. E, sem isso, todos os interessantes planos do estúdio converteram-se em seca teoria, em fórmula científica. Convenci-me de que havia um grande abismo entre os sonhos do diretor de cena e sua realização, que o teatro se destina acima de tudo ao ator e não pode existir sem ele e que a nova arte necessita de novos atores com nova técnica. Não havia tais atores no estúdio, e percebi que ele estava condenado a malograr abjetamente. A única saída era criar um estúdio para diretores de cena e seu trabalho de encenação. Mas na época eu estava interessado em diretores de cena apenas na medida em que pudessem auxiliar a criatividade dos atores, em vez de ocultar as faltas dos atores. O estúdio de diretores de cena, por maravilhoso que pudesse ser, não respondia às minhas necessidades e sonhos, especialmente porque eu estava ficando cada vez mais desapontado com o trabalho de artistas, em tela, em pinturas, em papelão, nos meios externos da montagem e na parafernália da direção de cena. Todas as minhas esperanças prendiam-se ao ator e à construção de um sólido fundamento para a sua engenhosidade e técnica. Era perigoso abrir o estúdio, perigoso por causa da própria idéia devido à qual fora organizado. Uma boa idéia, mal apresentada, morre. Alêm disso, a Revolução de 1905 irrompera e Moscou não tinha tempo para o teatro. A abertura do novo empreendimento foi adiada. Se eu retardasse o desenlace, não poderia liquidar o estúdio pagando a todo o mundo, de maneira que fui forçado a fechá-lo às pressas"'(34).
\end{abstract}

Meierhold, em seu balanço das atividades do Teatro-Estúdio, confirma um dos pontos essenciais do alegado por Stanislávski, pois declara que "se os projetos não foram totalmente realizados, foi porque o elenco do Teatro-Estúdio havia sido composto antes de maio (momento da brusca mudança, da ruptura com a tradição Meininger), e porque era formado em sua maior parte de alunos dos cursos cênicos do Teatro de Arte. Depois de maio, isto é, no momento preciso em que o encenador começou os ensaios, tornou-se evidente que, para satisfazer as novas exigências do Teatro-Estúdio, havia necessidade de outro material, mais flexível e menos familiarizado com os encantos de um teatro já bem determinado. O Teatro-Estudio não tinha elenco...'(35). Entretanto, o aspecto nodal
32 Por estranho que pareça, precisamente neste contexto de missa teatral com os turßoulos simbolistas a espaIhar seu incenso diante de estáticos thar seu incenso diante de estalicos devolos em passiva espera de reinos heallicos, o ativismo inato de Meierhold e seu engagement politico en contravam força nas vibraçðes dioni slacas, para manifestar-se significativamente, ditando ao jovem diretor palavras como as que escreveu para a estréia de $A$ morte de Tintaglles no Trenuciou, Teatro-Estudio que pronunciou, com poucas alteraçoes, na apresenlaçăo em 19 de março de 1906, em Tfflis, dizendo: "Tentem, meus senhores e minhas senhoras, revoltar-se com Ygraine, năo contra a morte, mas contra o que faz morrer. Entáo a potência simbólica da pẹca tomará po ma torca gigantesca. ma morte consigo. Então, esta ilha, luga de açấo, torna-se nossa vida. $O$ cas telo, Iá adiante, que se oculta por trás destas árvores mortas e mornas, o castelo no fundo do planalto, de onde năo se va nem as montanhas azuis, nem culs, nem o mar, outro lado dos rochedos, este casteo, săo as prisoos. Tintagiles é a juventude confiante, bela, ideal e pura. E Alguém mata impiedosamente estes magnfficos jovens. As irmâs, as mães, as crianças estendem para o œu suas mấzinhas fracas, imploram clemencia, perdzo libertaça. Em  â, em vas. Ninguesm quer escutar, ninguém quer saber. Em nossa ilha gemem e perecem também milhares de seres tăo jovens, tăo magnificos quanto Tjntagiles". "Mot ớintroduction", in Ecrits.... p. 80.

33 Cf. Stanisıávski, op. cit., p. 336.

34 Idem, ibidem.

35 "Théatre-Studio", in Ecrits..., p. 90. 
da questão e do impasse que sobreveio talvez se recorte mais incisivamente no seguinte episódio narrado pelo cenógrafo Ulianov, ao descrever, em suas memórias, o ensaio geral de $A$ morte de Tintagiles: "Semi-obscuridade sobre o palco. Apenas as silhuetas das pessoas são visíveis. $O$ cenário $€$ plano sem bastidores, pende quase diante do proscênio. Isto é novo, e nova é também a fala rítmica dos atores, tal como ela vem do palco. A ação se desenvolve lentamente; $\varepsilon$ como se o tempo tivesse parado. De repente um grito de Stanislávski: “Luz!" Um tremor percorre o teatro, barulho, confusão. Sudeikin e Sapunov saltam de seus lugares bradando objeções. A voz de Stanislávski: "A platéia não pode suportar a escuridão no palco por muito tempo, os espectadores precisam ver os rostos dos atores". Sudeikin e Sapunov: "Mas o cenário foi feito para a semi-obscuridade, ele perde todo o sentido artístico na luz!'. Faz-se de novo silêncio, resta apenas a batida da fala medida dos atores. Mas tão logo a luz foi acesa o cenário todo ficou estragado. Os vários elementos foram desintegrados, os cenários e as figuras foram separados $^{(36)}$. Na verdade, torna-se visível que não foram arranhões superficiais, do tipo tão freqüente nas companhias teatrais e entre suscetibilidades artísticas competitivas, nem mesmo desacordos sobre o trabalho dos interpretes e a qualidade de seu desempenho, porém divergências básicas sobre a natureza do teatro e da obra cênica que se interpuseram entre as aspiraçōes inovadoras de Stanislávski, sempre a gravitar na esfera da representação mimética, por mais longe que fosse em sua pesquisa de arte no domfnio do imaginário, e as concepções efetivamente revolucionárias, voltadas para a invocação cênica de "realidades" afastadas ate então do palco, que Meierhold e seu grupo no Teatro-Estúdio começaram a pôr em cena. Entre a exposição ao natural da vida do homem e a iluminação simbólica de seu mundo não podia haver conciliação estética e composição teatral satisfatórias, mormente naquele momento em que o simbolismo no teatro lutava para estabelecer a sua originalidade e amplitude artísticas, justamente por contraposição ao naturalismo. $\mathrm{O}$ rompimento era inevitável.

O desaparecimento prematuro do Teatro-Estúdio impediu que as tendências atuantes em seu tablado fossem desenvolvidas e levadas a todas as suas conseqüências lógicas. O próprio Briussov, numa análise da contribuição das experiências do conjunto para a formulação de uma nova teatralidade, disse: "No Teatro-Estúdio, tentou-se em muitos sentidos romper com o realismo da cena contemporânea e tomar audaciosamente a convenção como princípio da arte teatral. Os movimentos deram a parte mais bela à plástica do que à imitação da realidade, e certos grupos pareciam afrescos de Pompéia reproduzidos em quadros vivos. Os cenários não se inquietavam com todas as exigências da realidade, os quartos não tinham teto, as colunas do castelo estavam rodeadas de espécies de lianas, etc. $\mathrm{O}$ diálogo ressoava sempre sobre o fundo de música, arrastando a alma do ouvinte para o mundo do drama de Maeterlinck. Mas, de outro lado, o hábito das tradiçōes do palco permanecia muito sensível, assim como o longo aprendizado no Teatro de Arte. Os atores estudavam os gestos convencionais com que sonhavam os pré-rafaelitas, mas nas entonaçōes se esforçavam, como antes, em atingir à verdade do diálogo, queriam que suas vozes transmitissem a paixão e as emoções tais como elas são expressas na vida. $\mathrm{O}$ cenário era convencional em seu conjunto, mas permanecia nitidamente realista nos detalhes. Lá onde terminava o trabalho do encenador começava o desempenho comum do ator, e percebia-se logo que os intérpretes eram maus e não tinham formação autêntica, nem temperamento. O Teatro-Estúdio provava a todos que dele se aproximavam que não se devia reconstruir um teatro sobre fundamentos antigos. Ou se devia prosseguir a construção Antoine-Stanislávski, ou então se devia recomeçar tudo pela base"(37).

Ainda assim, na tentativa de revelar o diálogo interior do novo drama por meio da música e do ritmo do movimento plástico, retraduzindo-o em conjuntos cênicos dispostos à maneira dos baixos-relevos e afrescos, Meierhold definiu não só importantes elementos de seu estilo pessoal de direção, modos de formar que através de todas as fases e transformações reapareceriam caracteristicamente, sob diferentes roupagens, em sua obra de encenador. Mas a experiência do Teatro-Estúdio teve também outro alcance de grande significação no contexto da história das correntes e das idéias na arte cênica moderna. Com efeito, foi em função de suas pesquisas que começou a articular-se efetivamente, no palco russo, a linguagem do simbolismo, ao mesmo tempo que, no esforço para informá-la, com tudo quanto ela propunha como sugestão, mistério, poesia, apreensão existencial, abertura formal e comunicação do inefável, se iniciava a grande época da estilização e do esteticismo do teatro teatral russo. 